\title{
APLIKASI IMPACT GENERATION BERBASIS WEB
}

\author{
Angel Corputy*1, Immanuela P. Saputro ${ }^{2}$, Junaidy B. Sanger ${ }^{3}$ \\ ${ }^{123}$ Program Studi Teknik Informatika; Fakultas Teknik \\ ${ }^{123}$ Universitas Katolik De La Salle Manado; Kombos - Kairagi I Manado, No.Telp:(0431) 871957 \\ e-mail: ${ }^{1} 13013036 @$ unikadelasalle.ac.id, ${ }^{2}$ isaputro@ unikadelasalle.ac.id, ${ }^{3}$ jsanger@unikadelasalle.ac.id
}

\begin{abstract}
Abstrak-Tulisan ini bertujuan untuk mengembangkan Aplikasi Impact Generation berbasis web. Aplikasi ini diharapkan dapat menyelesaikan permasalahan mengenai penyaluran informasi kepada jemaat, penyedia wadah penyaluran bakat, dan penyedia wadah konseling. Metode yang digunakan untuk membangun sistem adalah Rapid Application Development (RAD) yang terdiri dari Requirement Planning, User Design, Construction dan Cutover. Hasil yang diperoleh dari penelitian ini setelah diuji coba menunjukkan bahwa sistem yang telah dibangun, dalam hal ini Aplikasi Impact Generation berbasis web telah bekerja dengan baik dan sesuai dengan kebutuhan yakni: sesuai dengan persyaratan yang diminta, aplikasi dapat membantu penyaluran informasi kepada jemaat dan menyediakan wadah untuk penyaluran bakat dan konseling.
\end{abstract}

Kata Kunci-Impact Generation, Aplikasi, Web, RAD

\section{PENDAHULUAN}

Graha Bethany Wanea Plaza merupakan salah satu cabang gereja dari Successful Bethany Families, yang bergerak pada bidang kerohanian di wilayah Manado. Pada Graha Bethany terdapat banyak cabang pelayanan, ada beberapa cabang pelayanan yang membutuhkan manajemen informasi yang terorganisir dengan baik dalam menyalurkan informasi kepada jemaat. Informasi yang disalurkan antara lain jadwal ibadah, renungan (khotbah) setiap minggu, event yang akan diselenggarakan, dan lain sebagainya. Salah satu cabang pelayanan di lembaga ini adalah Impact Generation, yaitu cabang pelayanan yang lebih tertuju pada kalangan muda (SMP dan SMA). Cabang pelayanan ini sering mengalami kesulitan dalam penyaluran informasi kepada jemaat.

Graha Bethany telah memiliki website, namun proses penyaluran informasi mengenai Impact Generation belum maksimal karena informasi yang tertera di website hanyalah merupakan gambaran singkat tentang Impact Generation. Informasi yang disalurkan hanya berupa deskripsi dan jadwal ibadah. Dalam penyaluran informasi kepada jemaat, pihak Impact Generation masih menggunakan media BlackBerry Messenger, dimana para jemaat merasa bahwa penyaluran informasi melalui media tersebut tidak terlalu efektif karena banyak jemaat yang tidak memiliki akun BlackBerry Messenger. Para jemaat lebih memilih untuk mengakses sebuah web rohani untuk melihat renungan rohani daripada harus memiliki akun BlackBerry Messenger. Selain itu, penyaluran informasi melalui BlackBerry Messenger sangatlah terbatas. Penyaluran informasi melalui BlackBerry Messenger belum bisa mencakup salah satu fungsi dari Impact Generation, yaitu menyediakan wadah untuk penyaluran bakat dan pengarahan. Seiring berjalannya waktu, cabang pelayanan ini membutuhkan sebuah wadah yang lebih luas untuk penyaluran informasi yang berkaitan dengan Impact Generation dan wadah untuk penyaluran bakat dan pengarahan, dimana wadah tersebut dapat diakses dimana saja dan kapan saja.

Adapun tujuan dalam penelitian ini adalah untuk membangun sebuah aplikasi Impact Generation berbasis web agar dapat menyelesaikan permasalahan penyaluran informasi kepada jemaat, penyedia wadah penyaluran bakat, dan penyedia wadah konseling.

\section{TINJAUAN PUSTAKA}

\section{A. Aplikasi}

Aplikasi adalah perangkat lunak yang dibuat oleh suatu perusahaan komputer untuk mengerjakan tugas-tugas tertentu [1]. Selain itu, aplikasi merupakan program-program yang dibuat oleh suatu perusahaan komputer untuk para pemakai yang beroperasi dalam bidang umum, seperti pertokoan, komunikasi, penerbangan, perdagangan, dan sebagainya [2].

\section{B. Website}

Website adalah keseluruhan halaman-halaman web yang terdapat dalam sebuah domain yang mengandung informasi. Sebuah website biasanya dibangun atas banyak halaman web yang saling berhubungan. Hubungan antara satu halaman web dengan halaman web lainnya disebut dengan hyperlink, sedangkan teks yang dijadikan media penghubung disebut hypertext [3].

\section{HTML}

HTML (Hypertext Markup Language) adalah bahasa standar yang digunakan untuk menampilkan halaman web. Yang bisa dilakukan dengan HTML yaitu [4]:

1. Mengatur tampilan dari halaman web dan isinya

2. Membuat tabel dalam halaman web

3. Mempublikasikan halaman web secara online

4. Membuat form yang bisa digunakan untuk menangani registrasi dan transaksi via web.

5. Menambahkan objek-objek seperti citra, audio, video, animasi, java applet dalam halaman web.

6. Menampilkan area gambar (canvas) di browser.

Penanda perintah didalam HTML biasanya disebut TAG. TAG digunakan untuk menentukan tampilan dari dokumen HTML. TAG dalam HTML merupakan kata kunci khusus yang selalu dikelilingi oleh tanda lebih kecil ' $<$ ' dan tanda lebih besar '>'. Pada umumnya, TAG dalam HTML memiliki pasangan seperti $\langle$ title $\rangle$ dan $\langle/$ title $\rangle$. Bagian yang berada diantara TAG pembuka dan TAG penutup disebut elemen [5]. 


\section{CSS}

CSS (Cascanding Style Sheet) adalah suatu teknologi yang digunakan untuk memperindah halaman website (situs). Singkatnya, dengan menggunakan metode CSS ini akan mudah untuk mengubah situs secara keseluruhan. CSS mempunyai 2 bagian utama, yaitu selectors dan deklarasi. Yang dimaksud selectors biasanya element HTML yang ingin diubah, sedangkan deklarasi biasanya terdiri dari properti dan nilai. Properti itu sendiri adalah atribut style yang ingin diubah, dan setiap properti memiliki nilai [6].

\section{E. PHP}

PHP Hypertext Preprocessor atau disingkat dengan PHP ini adalah suatu bahasa scripting khususnya digunakan untuk web development [4]. Karena sifatnya yang server side scripting, maka untuk menjalankan PHP harus menggunakan web server. Kelebihan PHP antara lain:

1. PHP berbasis server side scripting, dimana PHP dapat melakukan tugas-tugas yang dilakukan dengan mekanisme CGI (Common Gateway Interface) seperti mengambil, mengumpulkan data dari database, bahkan menghasilkan halaman web dinamis.

2. Command line scripting pada PHP, cara kerjanya hampir sama yaitu script PHP tersebut digunakan untuk memproses sebuah job dan task.

3. PHP dapat membuat aplikasi desktop.

4. Digunakan untuk berbagai macam platform sistem operasi.

5. Mendukung berbagai macam web server, seperti Apache, Microsoft Internet Information Server, Personal Web Server, Netscape and iPlanet Servers, Oreilly Website Pro Server, Caudium, Xitami, dan OmniHTTPd.

6. Bersifat Object Oriented Programming atau prosedural.

\section{F. Basis Data}

Basis data (database) terdiri dari 2 kata, yaitu basis dan data. Basis dapat diartikan sebagai markas, gudang, dan tempat berkumpul. Sedangkan data adalah fakta yang mewakili suatu objek seperti manusia, barang, hewan, peristiwa, dan keadaan, yang direkam dalam bentuk angka, huruf, simbol, teks, gambar, bunyi, atau kombinasinya. Basis data dapat didefinisikan dalam sejumlah sudut pandang seperti:

1. Himpunan kelompok data yang saling berhubungan yang diorganisasi sedemikian rupa agar dapat dimanfaatkan kembali dengan cepat dan mudah.

2. Kumpulan data yang saling berhubungan yang disimpan secara bersama sedemikian rupa dan tanpa pengulangan (redudansi), untuk memenuhi berbagai kebutuhan.

3. Kumpulan file yang saling terhubung yang disimpan dalam media penyimpanan elektronis.

\section{G. DBMS}

Database Management System (DBMS) adalah perangkat lunak yang menangani semua pengaksesan database. Dengan DBMS, diharapkan basis data dapat dikelola dengan baik dan mudah dalam penggunaannya [8]. DBMS memiliki fungsi antara lain:

1. Data Definition artinya DBMS harus dapat mengolah dan pendefinisan data.

2. Data Manipulation artinya DBMS harus dapat menangani permintaan dari pemakai untuk mengakses data.

3. Data Security and Integrity artinya DBMS harus dapat memeriksa keamanan dan integritas data yang didefinisikan oleh DBA (Database Administrator). Untuk melaksanakannya dapat dilakukan sebagai berikut:

a. Data Recovery and Concurrency artinya DBMS harus dapat menangani kegagalan-kegagalan pengaksesan database yang dapat disebabkan oleh kesalahan sistem, dan kerusakan disk.

b. Data Dictionary artinya DBMS harus menyediakan kamus data yang berfungsi untuk identifikasi isi data pada sebuah database. Penambahan kamus data ini bertujuan untuk memudahkan pembacaan oleh sistem analis lain atau user terhadap data apa saja yang terdapat pada suatu sistem. Untuk pembuatan kamus data, perlu diperhatikan notasi apa saja yang digunakan.

\section{METODE PENELITIAN}

Pengembangan perangkat lunak akan mengikuti tahapantahapan sesuai dengan metodologi Rapid Application Development (RAD) dan Unified Modelling Language (UML) sebagai kakas dalam pengembangan perangkat lunak. RAD (Rapid Application Development) adalah pendekatan kelompok yang mempercepat pengembangan sistem informasi dan menghasilkan sistem informasi yang berfungsi. RAD sangat bergantung pada prototyping dan keterlibatan pengguna [9].

Tahapan-tahapan pembangunan sistem dengan menggunakan RAD adalah [9]:

\section{Requirements Planning}

Tahap ini bertujuan untuk membahas kebutuhan bisnis, ruang lingkup proyek, kendala, dan persyaratan awal sistem.

\section{User Design}

Tahap ini bertujuan untuk melakukan perancangan model yang mewakili semua proses.

\section{Construction}

Tahap ini bertujuan untuk mengembangkan aplikasi dan berfokus pada pembangunan aplikasi (pemrograman).

\section{Cutover}

Tahap ini merupakan tahapan akhir, yang bertujuan untuk melakukan pengujian dan memberikan pelatihan kepada pengguna.

Dalam pembangunan perangkat lunak ini, kakas yang digunakan adalah UML (Unified Modelling Language). UML merupakan sebuah standarisasi bahasa pemodelan untuk pembangunan perangkat lunak yang dibangun dengan menggunakan teknik pemrograman berorientasi objek. UML muncul karena adanya kebutuhan pemodelan visual untuk menspesifikasikan, menggambarkan, membangun, dan mendokumentasi dari sistem perangkat lunak. UML hanya berfungsi untuk melakukan pemodelan. Jadi penggunaan UML tidak terbatas pada metodologi tertentu, meskipun pada 
kenyataannya UML paling banyak digunakan pada metodologi berorientasi objek [10]

\section{HASIL DAN PEMBAHASAN}

\section{A. Requirements Planning}

Daftar kebutuhan bisnis yang terdapat di Impact Generation dapat dilihat pada Tabel 1 berikut.

Tabel 1.

Daftar kebutuhan bisnis

\begin{tabular}{|l|l|l}
\hline \multicolumn{1}{|c|}{ Instansi } & \multicolumn{1}{c}{ Kebutuhan Bisnis } \\
\hline Impact Generation & a. $\begin{array}{l}\text { Pengguna, yaitu entitas yang berfungsi menyimpan } \\
\text { informasi mengenai pengguna yang mengakses aplikasi } \\
\text { berbasis web, yang mana pengguna tersebut dibedakan } \\
\text { berdasarkan tipe pengguna. }\end{array}$ \\
b. $\begin{array}{l}\text { Renungan, yaitu entitas yang berfungsi menyimpan } \\
\text { semua renungan setiap minggu yang sudah lewat } \\
\text { (berdasarkan khotbah pada hari minggu saat ibadah). }\end{array}$ \\
c. $\begin{array}{l}\text { Komentar Renungan, yaitu entitas yang berfungsi } \\
\text { menyimpan komentar-komentar yang terdapat pada } \\
\text { renungan. }\end{array}$ \\
d. $\begin{array}{l}\text { Bakat, yaitu entitas yang berfungsi menyimpan setiap } \\
\text { bakat beserta deskripsi masing-masing bakat yang ada di }\end{array}$ \\
$\begin{array}{l}\text { Impact Generation. } \\
\text { event, yaitu entitas yang berfungsi menyimpan semua } \\
\text { event, baik itu event yang akan diselenggarakan maupun } \\
\text { event yang telah diselenggarakan. }\end{array}$ \\
f. Chat, yaitu entitas yang berfungsi menyimpan pesan, baik \\
itu pesan yang berisi pertanyaan seputar pelayanan \\
Impact Generation maupun proses konseling.
\end{tabular}

Adapun ruang lingkup dari proyek ini adalah:

1. Mencari dan mengumpulkan data yang berhubungan dengan pembuatan aplikasi ini.

2. Menganalisis masalah dan kebutuhan.

3. Merancang dan membuat basis data, interface, dan proses untuk aplikasi yang akan dibangun.

4. Melakukan pemrograman dan pengujian terhadap aplikasi yang akan dibangun.

Beberapa fitur yang disediakan antara lain:

a. Untuk Admin (Sekretaris Impact Generation):

a) Fitur Login

b) Fitur Logout

c) Fitur Acara

d) Fitur Keanggotaan (Membership)

e) Fitur Kelompok Sel (Komsel)

f) Fitur Bakat

g) Fitur Renungan

h) Fitur Foto

i) Fitur Video

j) Fitur Persetujuan

b. Untuk Pengguna (Jemaat Impact Generation):
a) Fitur Sign-In
b) Fitur Login
c) Fitur Logout
d) Fitur Pencarian
e) Fitur Komentar
f) Fitur Chat

Informasi yang disalurkan kepada jemaat merupakan sumber masalah bagi pihak Impact Generation. Hal ini terjadi karena proses penyaluran informasi yang belum maksimal. Proses identifikasi dan analisis masalah serta mencari solusi terhadap masalah yang ada dapat dilihat pada Tabel 2 .

Tabel 2.

Problem Statement Matrix

\begin{tabular}{|l|l|}
\hline $\begin{array}{l}\text { Proyek : Aplikasi Impact Generation } \\
\text { Berbasis Web }\end{array}$ & Manager Proyek : Angel Corputty \\
\hline Dikerjakan oleh : Angel Corputty & Terakhir diperbarui oleh : Angel Corputty \\
\hline Tanggal pengerjaan : 29 September 2016 & Terakhir diperbarui : 20 Desember 2016 \\
\hline Masalah, Kesempatan, dan Pengarahan & Solusi yang Diusulkan \\
\hline $\begin{array}{l}\text { Staf kesulitan menyalurkan hal-hal yang } \\
\text { berkaitan dengan Impact Generation kepada } \\
\text { jemaat. }\end{array}$ & $\begin{array}{l}\text { Membangun Aplikasi Impact Generation } \\
\text { Berbasis Web untuk memudahkan penyaluran } \\
\text { informasi serta hal-hal lainnya yang berkaitan } \\
\text { dengan Impact Generation. }\end{array}$ \\
\hline
\end{tabular}

Daftar persyaratan awal sistem diperoleh dari hasil pengumpulan data, dimana salah satu cara pengumpulan data yang dilakukan adalah wawancara untuk mengetahui permasalahan yang terjadi di Graha Bethany Wanea Plaza Manado terutama di Impact Generation. Hasil wawancara kemudian dianalisis sehingga dapat membantu proses pembuatan Aplikasi Impact Generation Berbasis Web.

\section{B. User Design}

Use case diagram menggambarkan hubungan antara aktor dan sistem. Aktor yang terlibat dibagi menjadi dua, yaitu Admin dan Pengguna. Interaksi antara aktor dan sistem dapat dilihat pada Gambar 1, dimana penggambaran use case sistem baru dipisahkan berdasarkan aktifitas Actor.

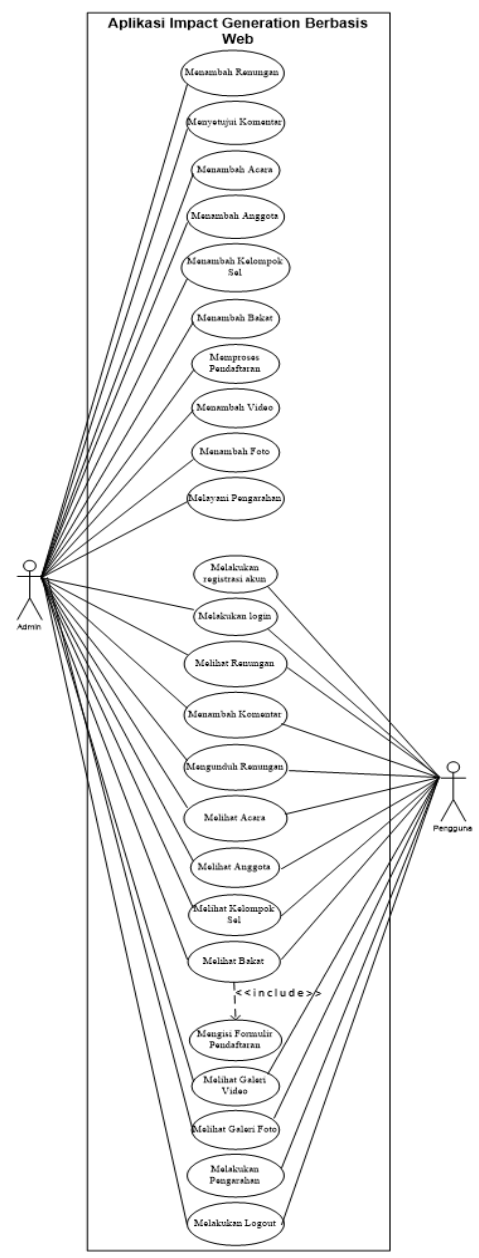

Gambar 1. Use Case Diagram Sistem Baru 
Berikut ini merupakan class diagram sistem baru, dimana class diagram ini dipecah menjadi dua, yaitu class diagram sistem baru bagi admin yang ditunjukkan pada Gambar 2 dan class diagram sistem baru bagi pengguna yang dapat dilihat pada Gambar 3.

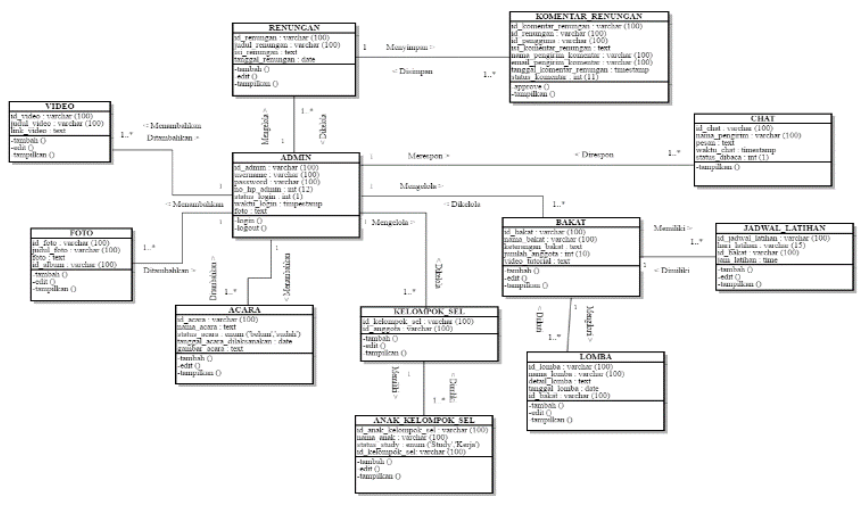

Gambar 3. Class diagram admin sistem baru

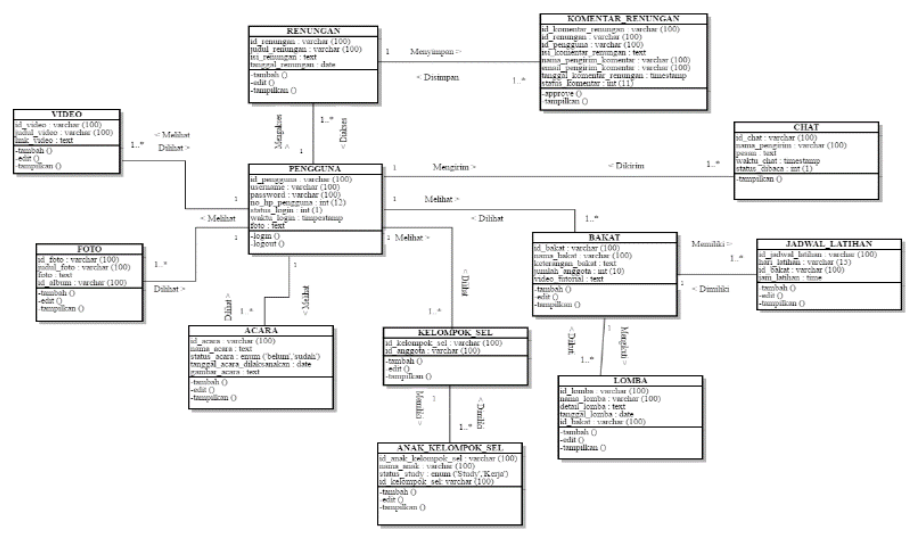

Gambar 4. Class diagram pengguna sistem baru

Selanjutnya, activity diagram yang bertujuan untuk menjelaskan hubungan antar objek dan fungsionalitas sistem dibuat menjadi dua yaitu activity diagram pengguna yang ditunjukkan pada Gambar 5 dan activity diagram admin yang ditunjukkan pada Gambar 6.

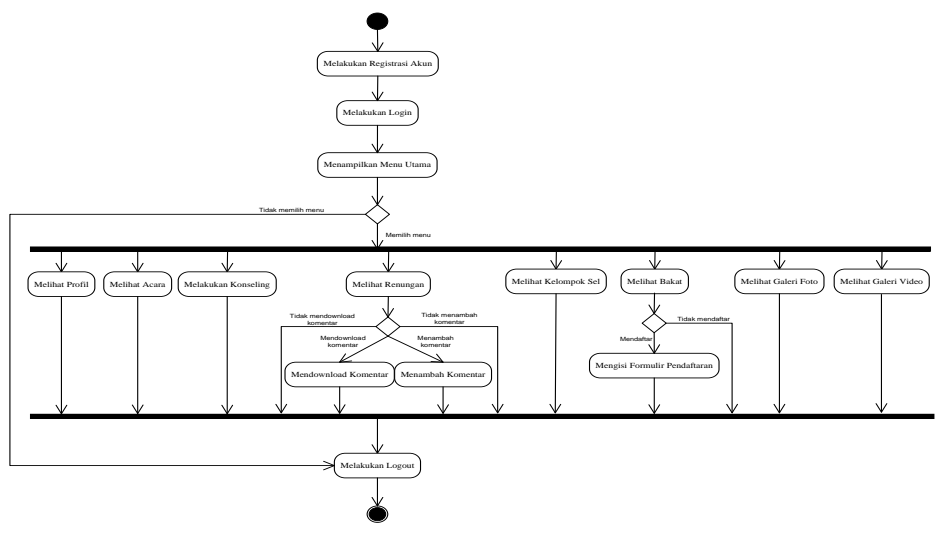

Gambar 5. Activity diagram admin sistem baru

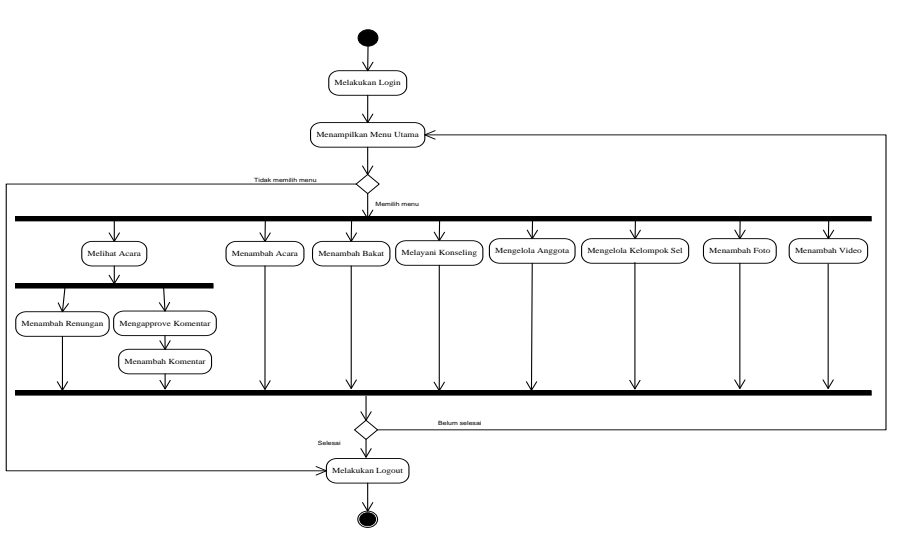

Gambar 6. Activity diagram pengguna sistem baru

Perancangan antarmuka digambarkan dengan storyboard. Perancangan tersebut dibuat sebagai acuan bagi aplikasi yang akan dibangun, dimana tampilan tersebut dibagi atas dua yaitu tampilan Admin dan Pengguna. Secara garis besar, kedua tampilan memiliki kesamaan, namun yang membedakan adalah pada tampilan Admin terdapat beberapa tombol untuk mengelola tampilan.

Desain halaman utama jemaat ditunjukkan pada Gambar 7. Desain halaman profil ditunjukkan pada Gambar 8. Desain halaman acara ditunjukkan pada Gambar 9. Desain halaman chat dan renungan ditunjukkan pada Gambar 10 dan Gambar 11.

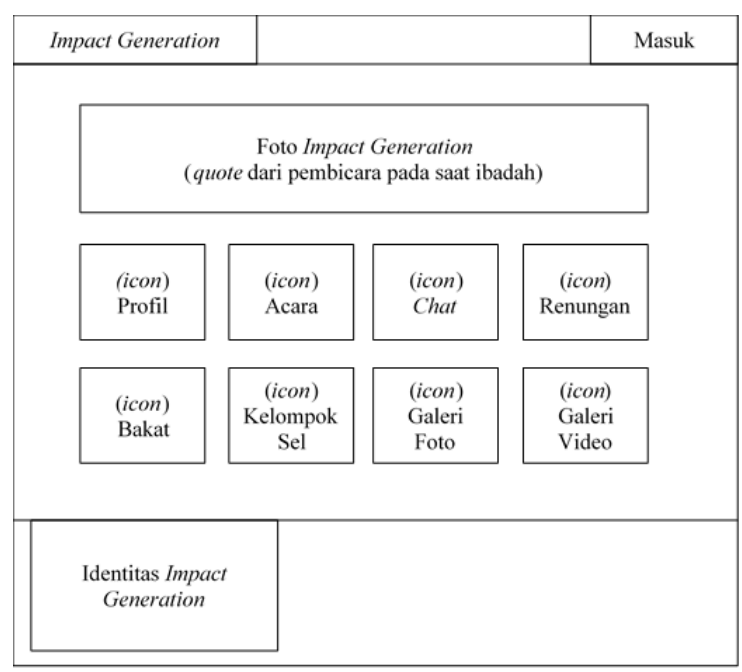

Gambar 7. Desain tampilan beranda

\begin{tabular}{|c|c|c|}
\hline Impact Generation & & Masuk \\
\hline (icon) Beranda & \multirow{2}{*}{ Profil Impact Generation } & \\
\hline (icon) Profil & & \\
\hline (icon) Acara & \multirow{2}{*}{ Foto Staf } & \\
\hline (icon) Chat & & \\
\hline (icon) Renungan & \multirow{3}{*}{ Sejarah } & \\
\hline (icon) Bakat & & \\
\hline (icon) Kelompok Sel & & \\
\hline (icon) Galeri Foto & \multirow{2}{*}{$\begin{array}{l}\text { Daftar } \\
\text { Kepengurusan }\end{array}$} & \\
\hline (icon) Galeri Video & & \\
\hline $\begin{array}{c}\text { Identitas Impact } \\
\text { Generation }\end{array}$ & & \\
\hline
\end{tabular}

Gambar 8. Desain tampilan profil 


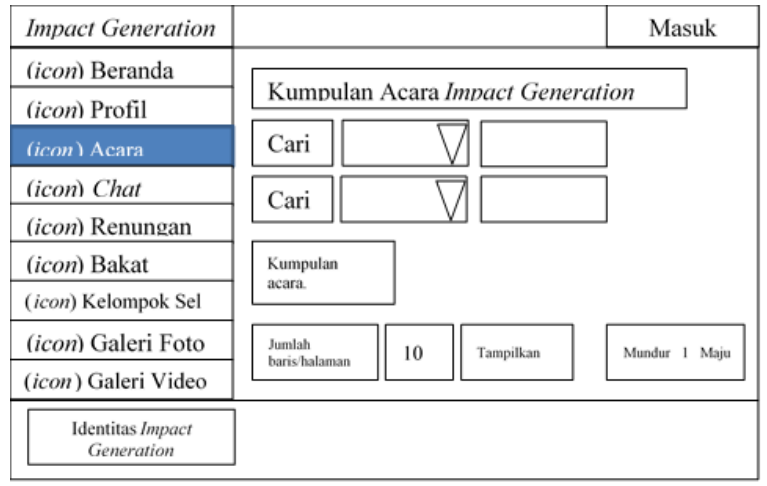

Gambar 9. Desain tampilan acara

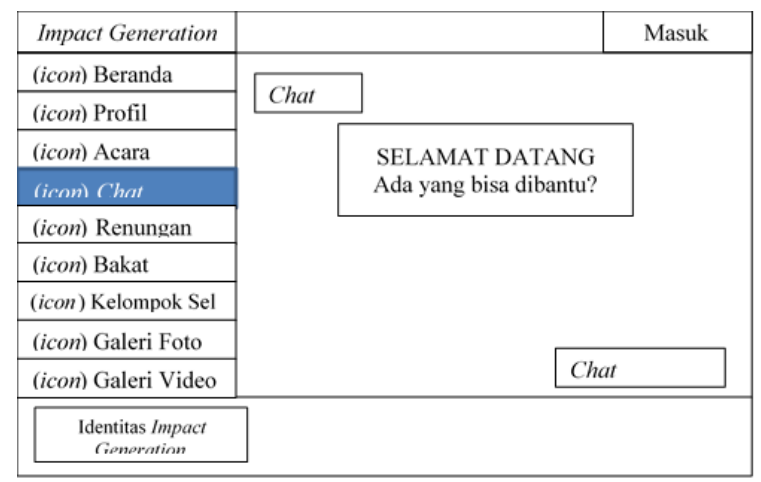

Gambar 10. Desain tampilan chat

\begin{tabular}{|c|c|c|c|c|}
\hline Impact Generation & & & & Masuk \\
\hline (icon) Beranda & \multirow{2}{*}{\multicolumn{4}{|c|}{ Renungan Mingguan Impact Generation }} \\
\hline (icon) Profil & & & & \\
\hline (icon) Acara & Cari & & & \\
\hline (icon) Chat & \multirow[t]{2}{*}{ Cari } & & & \\
\hline (irnn) Renunoan & \multirow{3}{*}{\multicolumn{3}{|c|}{ Daftar Renungan }} & \\
\hline (icon) Bakat & & & & \\
\hline (icon) Kelompok Sel & & & & \\
\hline (icon) Galeri Foto & \multirow[t]{2}{*}{$\begin{array}{l}\text { Jumlah } \\
\text { baris halaman }\end{array}$} & 10 & Tampilkan & Mundur I Maju \\
\hline (icon) Galeri Video & & & & \\
\hline $\begin{array}{c}\text { Identitas Impact } \\
\text { Generation }\end{array}$ & & & & \\
\hline
\end{tabular}

Gambar 11. Desain tampilan renungan

\section{Construction}

Tujuan dari tahapan ini adalah mengembangkan aplikasi dan melakukan pemrograman. Hasil dari tahapan ini adalah pengembangan aplikasi yang terdiri dari implementasi storyboard dan implementasi basis data serta melakukan pemrograman.

Gambar 12 menunjukkan tampilan awal dari aplikasi Impact Generation berbasis web. Pada tampilan ini terdapat beberapa menu yang dapat diakses oleh pengguna. Gambar 13 menunjukkan tampilan yang berisi informasi tentang Impact Generation. Pada tampilan ini terdapat informasi mengenai sejarah dan daftar kepengurusan yang terdapat didalamnya. Gambar 14 menunjukkan tampilan yang berisi informasi tentang acara yang akan atau telah diselenggarakan oleh Impact Generation. Gambar 15 menunjukkan tampilan yang mengizinkan pengguna yang telah memiliki akun untuk melakukan proses konseling. Gambar 16 menunjukkan tampilan yang berisi kumpulan renungan berdasarkan khotbah pada ibadah hari minggu yang sudah lewat.

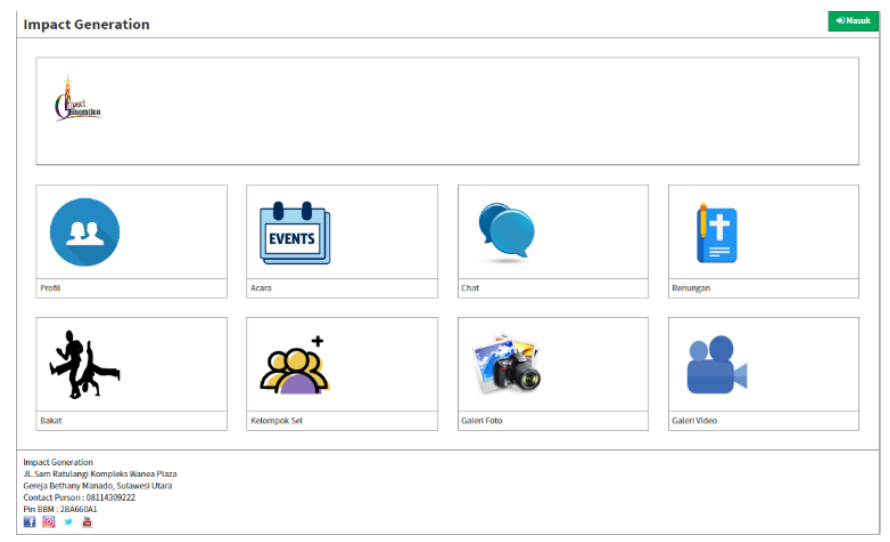

Gambar 12. Antarmuka beranda

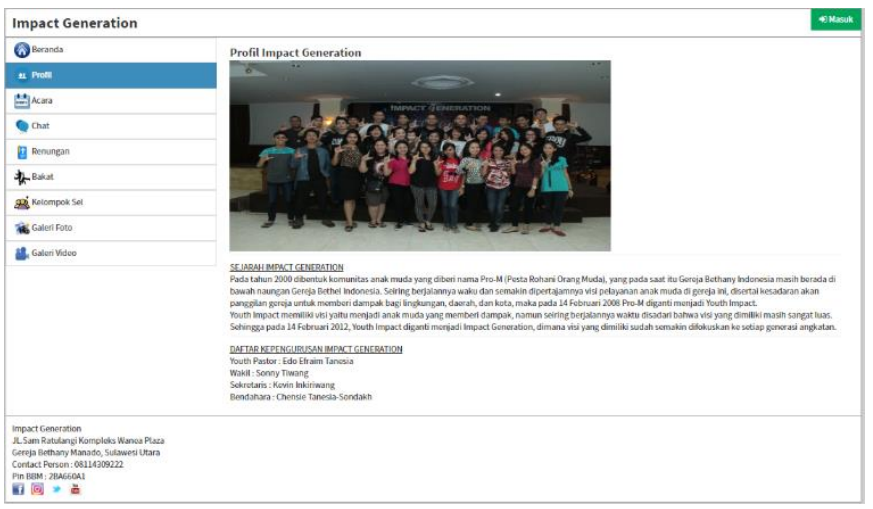

Gambar 13. Antarmuka profil

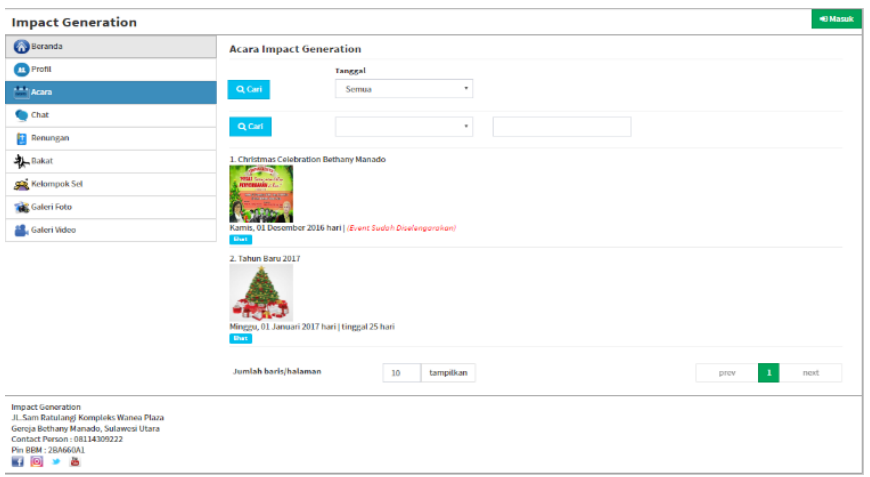

Gambar 14. Antarmuka acara

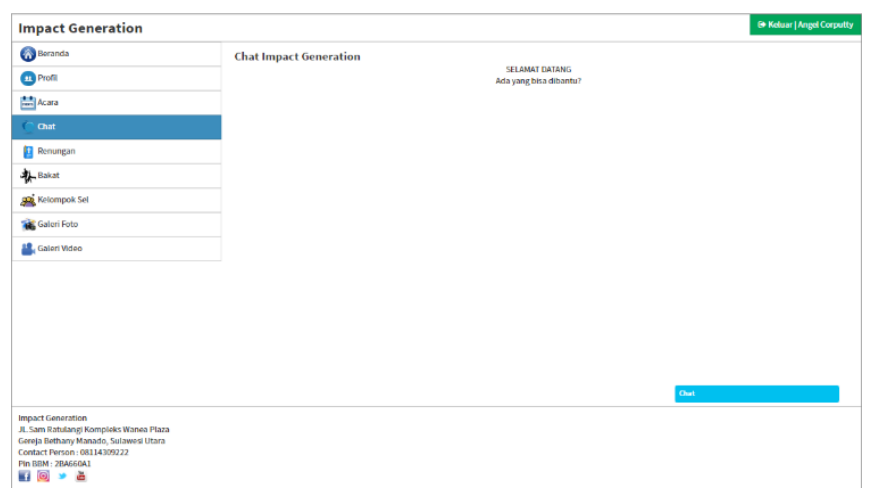

Gambar 15. Antarmuka chat 


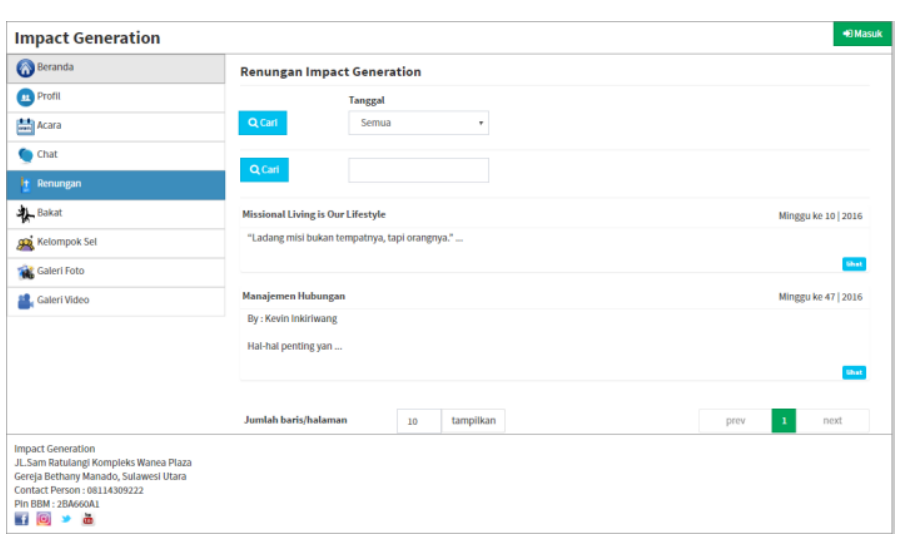

Gambar 16. Antarmuka renungan

Struktur database yang dibuat menggunakan PHPMyAdmin. Tabel pengguna, Tabel tipe pengguna, Tabel renungan, Tabel komentar renungan, Tabel bakat, Tabel lomba, Tabel jadwal latihan, Tabel kelompok sel, Tabel Anggota, Tabel anak kelompok sel, Tabel event, Tabel chat, Tabel direct chat, Tabel galeri foto, dan Tabel galeri video masing-masing ditunjukkan pada Gambar 17, 18, 19, 20, 21, 22, 23, 24, 25, 26, 27, 28, 29, 30, dan 31 .

\begin{tabular}{|c|c|c|c|c|c|}
\hline \# Nama & Jenis & Penyortiran & Atribut & Kosong & Bawaan \\
\hline 1 id_pengguna & $\operatorname{varchar}(100)$ & latin1_swedish_ci & & Tidak & Tidak ada \\
\hline 2 id_tipe_pengguna & $\operatorname{varchar}(20)$ & latin1_swedish_ci & & Tidak & Tidak ada \\
\hline 3 username & $\operatorname{varchar}(100)$ & latin1_swedish_ci & & Tidak & Tidak ada \\
\hline 4 password & $\operatorname{varchar}(100)$ & latin1_swedish_ci & & Tidak & Tidak ada \\
\hline 5 nama_pengguna & $\operatorname{varchar}(200)$ & latin1_swedish_ci & & Tidak & Tidak ada \\
\hline 6 no_telp_pengguna & int(12) & & & Tidak & Tidak ada \\
\hline 7 status_login & $\operatorname{int}(1)$ & & & Tidak & Tidak ada \\
\hline 8 waktu_login & timestamp & & & Tidak & CURRENT_TIMESTAMP \\
\hline 9 foto & text & latin1_swedish_ci & & Tidak & Tidak ada \\
\hline 10 session_id & $\operatorname{varchar}(200)$ & latin1_swedish_ci & & Ya & NULL \\
\hline 11 status_pengguna & enum('aktif', 'tidak_aktif') & latin1_swedish_ci & & Tidak & Tidak ada \\
\hline
\end{tabular}

Gambar 17. Tabel pengguna

\begin{tabular}{|c|c|c|c|c|c|}
\hline \# Nama & Jenis & Penyortiran & Atribut & Kosong & Bawaan \\
\hline 1 id_tipe_pengguna & $\operatorname{varchar}(100)$ & latin1_swedish_ci & & Tidak & Tidak ada \\
\hline 2 nama_tipe_pengguna & $\operatorname{varchar}(100)$ & latin1_swedish_ci & & Tidak & Tidak ada \\
\hline 3 keterangan & text & latin1_swedish_ci & & Ya & NULL \\
\hline
\end{tabular}

Gambar 18. Tabel tipe pengguna

\begin{tabular}{|c|c|c|c|c|c|}
\hline $\begin{array}{l}\text { \# Nama } \\
1 \text { id_renungan }\end{array}$ & $\begin{array}{l}\text { Jenis } \\
\text { varchar }(100)\end{array}$ & $\begin{array}{l}\text { Penyortiran } \\
\text { latin1_swedish_ci }\end{array}$ & Atribut & $\begin{array}{l}\text { Kosong } \\
\text { Tidak }\end{array}$ & $\begin{array}{l}\text { Bawaan } \\
\text { Tidak ada }\end{array}$ \\
\hline 2 judul_renungan & $\operatorname{varchar}(100)$ & latin1_swedish_ci & & Ya & NULL \\
\hline 3 isi_renungan & text & latin1_swedish_ci & & Ya & NULL \\
\hline 4 tanggal_renungan & date & & & Tidak & Tidak ada \\
\hline
\end{tabular}

Gambar 19. Tabel renungan

\begin{tabular}{|c|c|c|c|c|c|}
\hline $\begin{array}{l}\text { \# Nama } \\
1 \text { id_komentar_renungan }\end{array}$ & $\begin{array}{l}\text { Jenis } \\
\text { varchar(100) }\end{array}$ & $\begin{array}{l}\text { Penyortiran } \\
\text { latin1_swedish_ci }\end{array}$ & Atribut & $\begin{array}{l}\text { Kosong } \\
\text { Tidak }\end{array}$ & $\begin{array}{l}\text { Bawaan } \\
\text { Tidak ada }\end{array}$ \\
\hline 2 id_renungan & $\operatorname{varchar}(100)$ & latin1_swedish_ci & & Ya & NULL \\
\hline 3 id_pengguna & $\operatorname{varchar(100)}$ & latin1_swedish_ci & & Ya & NULL \\
\hline 4 isi_komentar_renungan & text & latin1_swedish_ci & & Ya & NULL \\
\hline 5 nama_pengirim_komentar & $\operatorname{varchar}(100)$ & latin1_swedish_ci & & Ya & NULL \\
\hline 6 email_pengirim_komentar & $\operatorname{varchar}(100)$ & latin1_swedish_ci & & Ya & NULL \\
\hline 7 tanggal_komentar_renungan & timestamp & & & Ya & CURRENT_TIMESTAMP \\
\hline 8 status_komentar & $\operatorname{int}(11)$ & & & Tidak & Tidak ada \\
\hline
\end{tabular}

Gambar 20. Tabel komentar renungan

\begin{tabular}{|c|c|c|c|c|c|}
\hline \# Nama & Jenis & Penyortiran & Atribut & Kosong & Bawaan \\
\hline 1 id_bakat & $\operatorname{varchar}(100)$ & latin1_swedish_ci & & Tidak & Tidak ada \\
\hline 2 nama_bakat & $\operatorname{varchar}(100)$ & latin1_swedish_ci & & Tidak & Tidak ada \\
\hline 3 keterangan_bakat & text & latin1_swedish_ci & & Ya & NULL \\
\hline 4 jumlah_anggota & $\operatorname{int}(10)$ & & & Tidak & Tidak ada \\
\hline 5 video_tutorial & text & latin1_swedish_ci & & Ya & NULL \\
\hline
\end{tabular}

\# Nama Jenis Penyortiran Atribut Kosong Bawaan 1 id_lomba varchar(100) latin1_swedish_ci Tidak Tidak ada 2 nama_lomba varchar(100) latin1_swedish_ci_ Tidak Tidak ada 3 detail_lomba text latin1_swedish_ci Ya NULL

4 tanggal_lomba date Tidak Tidak ada

5 id_bakat $\quad$ varchar(100) latin1_swedish_ci $\quad$ Ya NULL Gambar 22. Tabel lomba

\begin{tabular}{llllll} 
\# Nama & Jenis & Penyortiran & Atribut & Kosong Bawaan \\
1 id_jadwal_latihan & varchar(100) & latin1_swedish_ci & Tidak & Tidak ada \\
\hline 2 hari_latihan & varchar(15) & latin1_swedish_ci & Tidak & Tidak ada \\
\hline 3 id_bakat & text & latin1_swedish_ci & Ya & NULL \\
\hline 4 jam_latihan & time & & Tidak & Tidak ada
\end{tabular}

Gambar 23. Tabel jadwal latihan

$\begin{array}{llllll}\text { \# Nama } & \text { Jenis } & \text { Penyortiran } & \text { Atribut Kosong } & \text { Bawaan } \\ 1 \text { id_kelompok_sel } & \operatorname{varchar}(100) & \text { latin1_swedish_ci } & \text { Tidak } & \text { Tidak ada } \\ \text { 2 id_anggota } & \operatorname{varchar}(100) & \text { latin1_swedish_ci } & \text { Tidak } & \text { Tidak ada }\end{array}$

Gambar 24. Tabel kelompok sel

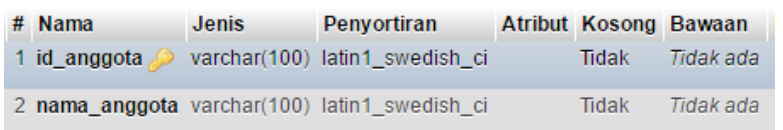

Gambar 25. Tabel anggota

\begin{tabular}{lllll} 
\# Nama & Jenis & Penyortiran & Atribut Kosong Bawaan \\
\hline 1 id_anak_kelompok_sel & varchar(100) & latin1_swedish_ci & Tidak & Tidak ada \\
\hline 2 nama_anak & varchar(100) & latin1_swedish_ci & Tidak & Tidak ada \\
3 status_study & enum('Study'. 'Kerja') latin1_swedish_ci & Tidak & Tidak ada \\
\hline 4 id_kelompok_sel & varchar(100) & latin1_swedish_ci & Ya & NULL
\end{tabular}

Gambar 26. Tabel anak kelompok sel

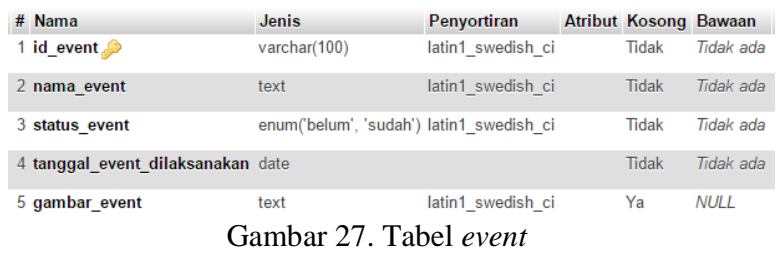

\begin{tabular}{|c|c|c|c|c|c|}
\hline \# Nama & Jenis & Penyortiran & Atribut & Kosong & Bawaan \\
\hline 1 id_chat & varchar(100) & latin1_swedish_ci & & Tidak & Tidak ada \\
\hline 2 nama_pengirim & varchar(100) & latin1_swedish_ci & & Tidak & Tidak ada \\
\hline 3 email_pengirim & varchar(100) & latin1_swedish_ci & & Tidak & Tidak ada \\
\hline 4 pesan & text & latin1_swedish_ci & & Tidak & Tidak ada \\
\hline 5 id_pengguna & varchar(100) & latin1_swedish_ci & & Tidak & Tidak ada \\
\hline 6 id_penerima & varchar(100) & latin1_swedish_ci & & Tidak & Tidak ada \\
\hline 7 waktu_chat & timestamp & & & Ya & CURRENT_TIMESTAMP \\
\hline status_dibaca & int(1) & & & Tidak & Tidak ada \\
\hline
\end{tabular}

Gambar 28. Tabel chat

\begin{tabular}{|c|c|c|c|c|c|}
\hline \# Nama & Jenis & Penyortiran & Atribut & Kosong & Bawaan \\
\hline 1 id_direct_chat & $\operatorname{varchar}(100)$ & latin1_swedish_ci & & Tidak & Tidak ada \\
\hline 2 id_pengguna & $\operatorname{varchar}(100)$ & latin1_swedish_ci & & Tidak & Tidak ada \\
\hline 3 isi_direct_chat & text & latin1_swedish_ci & & Tidak & Tidak ada \\
\hline 4 waktu_direct_chat & timestamp & & & Ya & CURRENT_TIMESTAMP \\
\hline 5 id_penerima & $\operatorname{varchar}(100)$ & latin1_swedish_ci & & Tidak & Tidak ada \\
\hline 6 status_dibaca & $\operatorname{int}(1)$ & & & Tidak & Tidak ada \\
\hline
\end{tabular}

Gambar 29. Tabel direct chat 


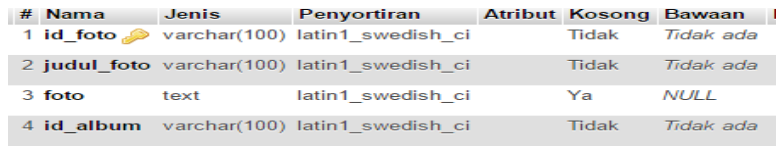

Gambar 30. Tabel galeri foto

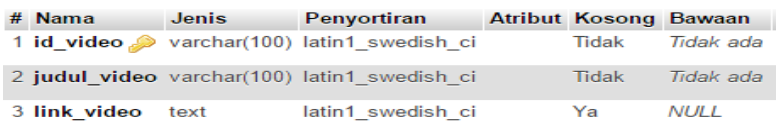

Gambar 31. Tabel galeri video

Berikut ini script untuk fitur chat

$<$ ?php

include ".././admin/php/config.php";

include ".././admin/php/myFunction.php"

\$date $=$ date $(" Y-m-d$ H:i:s") :

id = myGenerateId (\$database, "direct chat", "DC", 10),

\$query = my mysql query ("INSERT INTO direct chat (id direct chat,

id pengguna, id penerima, isi direct chat, waktu direct chat)

VALUES ('\$id', '\$_SESSION[id_pengguna] ', '\$POST[id]',

\$_POST[isi]', '\$date') ");

\$isi $=\operatorname{explode}(" \backslash n "$, \$_POST ['isi'])

\$isi $=$ implode $("<b r>", \quad$ isi);

echo "

<div class='direct-chat-msg right div send m' id chat='\$id'>

<div class='direct-chat-info clearfix'>

<span class='direct-chat-name pull-

right' $>$ \$_SESSION [nama_pengguna] $</$ span $>$

<span class='direct-chat-timestamp pull-

left'>". setDateToString2 (\$date). " </span> $</$ div $>$

$<$ img class='direct-chat-img'

src='admin/files/pengguna/images/\$_SESSION[foto] ' alt='message

user image'>

$<$ div class='direct-chat-text'>

$</$ div $>$

<small class='label detail' style='color: \#AAAAAA; ' $></$ small $1>$

$</ \operatorname{div}>$

";

\section{Cutover}

Pada tahap ini akan dijelaskan tentang tujuan pengujian dari aplikasi. Berikut tujuan dari pengujian aplikasi:

1. Memastikan apakah aplikasi yang telah dibangun sesuai dengan analisis dan perancangan yang dilakukan.

2. Mengetahui apakah manfaat dan kebutuhan pengguna telah terpenuhi atau belum terpenuhi.

3. Memastikan semua persyaratan pengguna dan sistem sudah dapat diimplementasikan.

4. Memastikan fungsi-fungsi dalam aplikasi telah berjalan sesuai dengan keinginan pengguna.

5. Mengetahui respons dari aplikasi apabila dimasukkan data.

6. Menerima respons dari pengguna mengenai aplikasi yang telah dibangun.

Berikut kriteria-kriteria dari aplikasi yang telah dibangun:

1. Aplikasi telah memenuhi persyaratan pengguna dan sistem.

2. Aplikasi mudah digunakan oleh pengguna.

3. Aplikasi sudah dapat membantu penyelesaian masalah.

4. Semua fungsi dalam aplikasi berjalan sesuai yang diharapkan.

Kasus pengujian dari aplikasi yang telah dibangun dapat dilihat pada Tabel 3 .
Tabel 3. Kasus pengujian

\begin{tabular}{|c|c|}
\hline No. & Titik Pemeriksaan \\
\hline \multirow{2}{*}{1.} & Fitur Login \\
\hline & Apakah username dan password yang dimasukkan dapat dibaca oleh sistem? \\
\hline \multirow{2}{*}{2.} & Fitur Sign-In \\
\hline & Apakah data akan ditambahkan ke dalam basis data jika berhasil mengisi detail data? \\
\hline \multirow[b]{2}{*}{3.} & Fitur Pencarian \\
\hline & $\begin{array}{l}\text { - Apakah aplikasi dapat menampilkan hasil yang dicari berdasarkan kata kunci y: } \\
\text { dimasukkan ke kolom pencarian? } \\
\text { - Apakah aplikasi dapat menampilkan hasil yang dicari berdasarkan kategori y: } \\
\text { dipilih? } \\
\text { Apakah aplikasi dapat menampilkan hasil yang dicari berdasarkan jumlah y؛ } \\
\text { dimasukkan? }\end{array}$ \\
\hline \multirow[b]{2}{*}{4.} & Fitur Chat \\
\hline & $\begin{array}{ll}- & \text { Apakah aplikasi dapat mengirim pesan? } \\
\text { - } & \text { Apakah aplikasi dapat menampilkan daftar admin yang sedang online? }\end{array}$ \\
\hline \multirow[b]{2}{*}{5.} & Fitur Komentar \\
\hline & $\begin{array}{ll} & \text { Apakah aplikasi dapat mengirim komentar? } \\
\text { - } & \text { Apakah aplikasi dapat menampilkan komentar? } \\
\text { - } & \text { Apakah admin dapat menyetujui komentar? }\end{array}$ \\
\hline \multirow[b]{2}{*}{6.} & Fitur Renungan \\
\hline & $\begin{array}{l}\text { - Apakah aplikasi dapat mengunduh renungan? } \\
\text { - Apakah aplikasi dapat menyimpan renungan yang baru ditambah atau diedit? } \\
\text { - Apakah admin bisa mengedit renungan? }\end{array}$ \\
\hline \multirow[b]{2}{*}{7.} & Tes Browser \\
\hline & $\begin{array}{l}\text { Apakah aplikasi dapat berjalan sebagaimana mestinya apabila diakses melalui brow } \\
\text { lainnya? }\end{array}$ \\
\hline \multirow[b]{2}{*}{8.} & Tampilan Galeri Foto \\
\hline & $\begin{array}{l}\text { - Apakah aplikasi dapat menampilkan album foto yang telah ada? } \\
\text { - Apakah album foto yang dibuat dan foto yang ditambahkan ke dalam album } \mathrm{f} \\
\text { berhasil disimpan? } \\
\text { Apakah foto yang memiliki ekstensi diluar yang telah ditetapkan (bmp, png, jpg, , } \\
\text { jpeg) berhasil diunggah? } \\
\text { Apakah foto yang ukurannya melebihi 1MB berhasil diunggah? }\end{array}$ \\
\hline \multirow[b]{2}{*}{9.} & Tampilan Bakat \\
\hline & $\begin{array}{l}\text { Apakah video yang memiliki ekstensi diluar yang telah ditetapkan (mkv, avi, mp4, } \\
\text { 3gp) berhasil diunggah? } \\
\text { Apakah video yang ukurannya melebihi 500MB berhasil diunggah? }\end{array}$ \\
\hline \multirow[b]{2}{*}{10.} & Fitur Logout \\
\hline & Apakah peng \\
\hline
\end{tabular}

\section{KESIMPULAN DAN SARAN}

Beberapa hal yang dapat disimpulkan dari pembangunan Aplikasi Impact Generation Berbasis Web adalah sebagai berikut:

1. Aplikasi Impact Generation Berbasis Web telah berhasil dibangun.

2. Aplikasi Impact Generation Berbasis Web dapat berjalan dengan baik sesuai dengan persyaratan yang diminta.

3. Aplikasi dapat membantu penyaluran informasi kepada jemaat dan menyediakan wadah untuk penyaluran bakat dan konseling.

Adapun saran bagi pengembangan aplikasi Impact Generation berbasis web selanjutnya adalah sebagai berikut:

1. Penambahan renungan dalam bentuk audio $(\mathrm{mp} 3)$

2. Pengembangan ke platform mobile

\section{DAFTAR PUSTAKA}

[1] Dhanta, R. (2009). Pengantar Ilmu Komputer. Surabaya: Indah.

[2] Sutarman. (2009). Pengantar Teknologi Informasi. Yogyakarta: Bumi Aksara.

[3] Sovia, R., Febio, J. (2009). Membangun Aplikasi E-Library Menggunakan HTML, PHP Script, dan MySql Database.

[4] Hidayatullah, P., Kawistara, JK. (2014). Pemrograman Web. Bandung: Informatika. 
[5] Asmi, F. (2015). Berkenalan dengan HTML. Jakarta: Fauzan Azmi.

[6] Prasetio, A. (2014). Buku Sakti Webmaster. Jakarta: Mediakita.

[7] Yanto, R. (2016). Manajemen Basis Data Menggunakan MySQL. Yogyakarta: Deepublish

[8] Lubis, A. (2016). Basis Data Dasar. Yogyakarta: Deepublish

[9] Shelly, GB., Rosenblatt, HJ. (2012). Rapid Application Development in System Analysis and Design $9^{\text {th }}$ Edition. USA: Course Technology

[10] Sukamto, RA., Shalahuddin, M. (2015). Rekayasa Perangkat Lunak Terstruktur Dan Berorientasi Objek. Bandung: Informatika. 